International Journal of Child, Youth and Family Studies (2012) 1: 65-82

\title{
SOCCER CASUALS: A SLIGHT RETURN OF YOUTH CULTURE
}

\section{Steve Redhead}

\begin{abstract}
This essay reports from a long-term research project ${ }^{1}$ which interviewed participants in a post-war U.K. youth culture called "casuals" about all aspects of its history, especially the styles of music and fashion and its connection to British soccer spectatorship from the late 1970s to the present day. Original interview and ethnographic material from the project is presented and discussed, and situated within a context of the sociology of youth culture in general and soccer fandom in particular. The essay suggests some theoretical and methodological signposts for the future study of youth culture whilst outlining some specific aspects of the research conducted. This new work on youth culture also rethinks earlier work on rave culture and football hooligan subcultures in the light of appreciation and critique of such work in various recent youth subcultural theory debates. The research reported on here mapped the history of the "moments" of the birth of casual in the late 1970s and the coming together of the football hooligan and rave subcultures in the late 1980s and early 1990s, as well as the later remixing, recycling and "mash up" of these moments in a present in which "pop culture" is said by some to be "addicted to its own past” (Reynolds, 2011).
\end{abstract}

Keywords: casuals, soccer hooliganism, youth culture, youth subculture, fashion, music, hooligan memoirs, independent publishing

Acknowledgements: Thanks to our research team, especially to graduate students Ben Horne and Simon Penny, for their rigorous work on the project, and all the many participants who generously gave their time to be interviewed.

Steve Redhead, Ph.D is Professor of Legal Studies, Faculty of Social Science and Humanities, University of Ontario Institute of Technology (UOIT), 2000 Simcoe Street North, Oshawa, ON, Canada, L1H 7K4, (905) 721-8668.

Steve.Redhead@uoit.ca 
International Journal of Child, Youth and Family Studies (2012) 1: 65-82

\section{Casuals and Youth Culture}

Casual history, or history of the casual, in many ways, is a missing key to some of the persistent problems in the study of the international history and sociology of youth culture, especially in post-war Britain. “Casual” as a youth culture effectively started in the 1977-1978 soccer season (Allt, 2004, 2007) yet it is still a youth culture which is rarely featured in the global output of academic work on youth culture and youth subculture (Gelder, 2007; Jencks, 2005) almost 40 years later. Nevertheless, occasionally, it is briefly discussed; for example, Bill Osgerby, in a sweeping overview of youth in Britain since 1945 (Osgerby, 1998, p. 161), notes correctly that although "in their celebration of conspicuous consumption the casuals appeared to embody the free market ethos" of the Thatcher Government, "casual style”, beginning in the late 1970s just before Margaret Thatcher became Prime Minister, was "more complex than a straightforward endorsement of the 'enterprise culture”, a phrase recently resurrected in political discourse when U.K. Prime Minister David Cameron led his coalition government into Downing Street in May 2010.

Casual youth culture and its relationship to soccer hooligan violence since the late 1970s has featured prominently in the overtly "pulp” soccer hooligan memoirs published by independent companies such as Milo Books situated in the north west of England. As the publisher of Phil Thornton's classic account of this youth culture, a book entitled Casuals: Football, Fashion and Fighting: The Story of a Terrace Cult (Thornton, 2003), Milo Books' owner Pete Walsh astutely pointed out in the course of the research project which we conducted (all following quotations are from the research project transcripts):

The casual movement has been underestimated in British style culture, starting as it did outside the gaze of the fashion media, who did not pick up on it for several years - I think the New Musical Express may have been the first mainstream publication to allude to it in a story about the Liverpool fanzine The End. Chronicling this movement is extremely difficult because there is little material of record; it is all personal reminiscence, which is notoriously unreliable. Even decent early photographs are hard to come by. Phil Thornton did a very good job of pulling different strands together and of charting the progress and changes the fashions underwent.

The remixing and recycling of casual youth culture is widespread. One of the best ethnographic accounts of "scally" culture - what became better known as casual youth culture over the subsequent years - is in Awaydays, the debut novel of Kevin Sampson (1998), the exmanager of Merseyside band, The Farm (most famous for their international chart hit All Together Now). Awaydays is based "fictionally" around a group of Tranmere Rovers soccer "lads" in the late 1970s called The Pack but written with unerring sociological accuracy. A film version of Awaydays, directed by Pat Holden, was released in $2009^{2}$, complete with a highly evocative post-punk soundtrack by the likes of Echo and the Bunnymen, Joy Division, Magazine, and Ultravox, and the "cult" novel itself was republished with a new cover to coincide with the film's release as a DVD. The previous year, in 2008, a "cool modernist” (Redhead, 2011) artistically produced second edition of Dave Hewitson's autobiographical casual memoir The Liverpool Boys Are In Town: The Birth of Terrace Culture came onto the marketplace, designed by the Eleanor Suggett Studio and published by Liverpool's Bluecoat 
International Journal of Child, Youth and Family Studies (2012) 1: 65-82

Press. In addition, a long awaited anthology of The End fanzine, originally edited by Peter Hooton, singer in The Farm (Allt, 2007; Redhead, 1991a, 1991b), and widely regarded as the bible for the widely labelled "scally" culture in the 1980s, was scheduled to be published by Bluecoat Press as part of the City of Liverpool's year as Europe's Capital of Culture, or “Culture of Capital” as Nicky Allt (2008) smartly satirised it. The history of casual youth culture, and its connection to football hooligan violence (Zatich \& de Leeuw, 2010), also has pervasive contemporary interest on numerous Internet website forums and some parts of the research project monitored these sites (Redhead, 2010a, 2010b). This was predicated on the idea that the connections between various forms of subcultural literature (fanzines, e-zines, Internet forums, websites, social networking sites, book memoirs, films, videos, photos) and youth cultures like casuals need to be taken seriously within contemporary studies of youth culture.

\section{Sub-Culture: Conversations From A Research Project}

I want to now quote some further interview transcripts from the research and suggest some theoretical and methodological signposts for the study of subculture, whilst also outlining some key aspects of the research conducted. This research work into British youth culture also rethinks earlier work on rave culture (Redhead, 1990, 1993a, 1993b; Anderson \& Kavanaugh, 2007; Osgerby, 2004, pp. 87-92) and soccer hooligan subcultures (McLaughlin \& Redhead, 1985; Redhead, 1987, 1991a, 1991b, 1997a, 1997b, 2000, 2004; Redhead, Wynne, \& O’Connor, 1997; Osgerby, 1998) in the light of appreciation and critique of such work in recent youth subcultural theory debates (Blackshaw \& Crabbe, 2004; Blackman, 2005; Hesmondalgh, 2005; Bennett, 2005; Greener \& Hollands, 2006; Hall \& Jefferson, 2006). The research shows that although casual as a youth culture or youth subculture disappeared from the mainstream media gaze for a time, there remain elements or traces of such "real" youth cultures and youth subcultures today, often in hybrid guises. The argument is that there is something of a comeback (or "slight return" as I call it, borrowing from the title a version of Jimi Hendrix's Voodoo Chile from the 1960s) of casual youth culture initially seen by commentators and the media as a transient, postmodern youth culture - in the 21st century (Redhead, 2008b, 2008c, 2010a, 2010b; Thornton, 2003) and a possibility now of reconstructing, through careful and rigorous research, a long-term history of casual youth culture.

Casual youth culture in Britain, as has already been emphasised, began in the late 1970s, after the heyday of skinheads and mods (Daniel \& Maguire, 1972; Jefferson \& Hall, 2006; Healy, 1996; Osgerby, 1998; Hewitt, 2000; Hewitt \& Baxter, 2004). Indeed, skinhead and other pre-casual youth cultures pervaded much of the initial parts of the interviews we conducted for the research project. Chris Brown, author of a Bristol Rovers soccer fan memoir steeped in the context of 1970s skinhead music and fashion (Brown, 2000), which was later considerably revised in a new edition with a new title (Brown, 2009), claimed to our interviewer that it was indeed the music and fashion, rather than football gang fighting, that secured his original book contract:

I set out to write my memories of the 1970s - music, fashion and the behaviour that went with it. That's what I was doing week in and week out - football hooliganism. First 
International Journal of Child, Youth and Family Studies (2012) 1: 65-82

I got talking to Skinhead Times (ST) Publishing, George Marshall. George Marshall's a bloke who's not interested in making money. I offered it to him and he bit my hand off. But you never see their books in the shops. So I reconsidered. I sent off the complete manuscript to Random House, Milo Books, and Hodder Headline. They all said they'd do it, within a few weeks. I've learnt. They all say this. They might take months. Then it just never happens. Then a bloke I work with left a message on my answer machine. "There's a publisher wants to publish your book". That was John Blake. He was a music journalist back in the 1970s. He was interested in the music.

Casual youth culture is still pervasive in British culture today, characterised by interest in particular "labelled" clothing, footwear, and general attire, and occasionally crossing the trajectory of so-called "chav" culture, the burgeoning underclass "white trash" of tabloid legend where the British working class is ritually “demonised” (Jones, 2011). Stories of casual youth culture are overwhelmingly male and white but there are some signs that this is changing to include popular memory of, for instance, British Asian football casual culture (Khan, 2010; Burdsey, 2008). Casual, long lasting and internationalised, has in fact been far from the transient youth culture predicted since the 1980s by some postmodern sociologists and criminologists, and many media outlets. Merseyside was the birthplace of what became casual youth culture quickly followed by Manchester and then London, and eventually most other towns and cities in the U.K. I concentrate mainly on our original research material relating to Manchester and Merseyside in the north west of England. The personal reminiscences of interviewees presented here are evocative and memorable but also controversial partly because of the nature of "oral history" research in youth culture studies. Although the "truth" of memoirs and memories has been often debated, writer and Milo Books publisher Pete Walsh argued to us that:

as for accuracy, it's impossible to say, as I wasn't there. But I do think all of my published authors have made efforts to put across reasonably balanced accounts. Out and out bragging doesn't work well in these books; they get laughed at.

The research presented here provides material for reflection and correction of previously mistaken assumptions. It adds to a rough popular memory (Brabazon, 2006) around sport sociology, cultural studies, youth culture, and the sociology of subcultures. It further identifies events and figures however partially, so that more sustained ethnographic, participant observation, work can be undertaken in future (Redhead, 2008b, 2008c, 2010a, 2010b). As Pete Walsh, media trained and a working journalist for many years, also said to our researchers:

academia is or should be concerned with rigorous analysis by the standards of that particular discipline. But you cannot exclude first person accounts from that. They might be self-serving or "narcissistic" but they contain a wealth of vital material not available elsewhere.

The history of casuals, and their relation to soccer hooligan gangs, is built up through our myriad interviews in the research project. As Pete Walsh's Milo Books proclaimed when initially releasing Perry Boys (Hough, 2007), a memoir of the "casual gangs of Manchester and Salford”, in 2007: 
International Journal of Child, Youth and Family Studies (2012) 1: 65-82

The Perry Boys are one of the great untold stories of modern youth culture. They emerged in the pivotal year of 1979 in inner-city Manchester and Salford, a mysterious tribe of football hooligans and trendsetters united by a new fashion. Their only counterparts at the time were the Scallies of Liverpool, who became their biggest rivals both on and off the terraces. As a young follower of Manchester United, Ian Hough witnessed first-hand how the bootboys of the infamous Red Army were slowly usurped by a small but fast-growing group of unlikely-looking pretenders. They sported Fred Perry polo shirts (hence the name), Lee cords, Adidas Stan Smith trainers and wedge haircuts. With their eclectic soundtrack and appetite for amphetamine-fuelled excess, they would transform their city into the clubbing and style capital of the country. (cover blurb, Hough, 2007)

Manchester, then, had its "Perry Boys" and Merseyside had its "Scallies" - and London, as can be seen below, eventually had its "Chaps". These were ostensibly, to the insiders at least, "glamorous hooligans" 3 but they were frequently involved in soccer gang violence and vandalism as a result of their fashion style, fierce territoriality, and obsessive soccer fandom. Ian Hough has written a subsequent casual memoir for another independent publisher, Pennant Books (run by former West Ham United hooligan Cass Pennant), called Perry Boys Abroad (Hough, 2009). As a former Manchester United casual with a long personal memory, he agreed to be one of our interviewees for the research project. As Hough (2007) recalls in his first memoir:

the nameless thing as it became known eventually mushroomed outwards from the North West of England. I have seen it writ by another, namely Andy Nicholls in his book Scally, that Tottenham brought the first cockney teams up in the early casual days to Goodison Park, Everton's ground on Merseyside. I agree 100\% with this picture. Tottenham came to Old Trafford in green windjammers, Doc Martens and skinheads in late October 1981, in the League Cup, and then we played them again in mid-April 1982 in the league and there they all were, in Ellesse and Tacchini trackies, black guys sporting gold and top training shoes... Leeds and Tottenham were properly the first lads to formulate a semblance of style outside the north west but the rest blundered along soon enough. (p. 116)

As he told our research interviewer, Hough's personal motivations for writing his two books about casuals were complex:

When I first bought a computer and discovered the Internet, I would surf for all kinds of stuff I didn't think I'd find. I was always amazed when I found info on obscure bands or bizarre scientific sub-sects, etc. One thing I really struggled to find any decent info on was that specific time period between 1978 and 1982 when football hooligans in the north west adopted the soul boy look. Being caught up in the middle of it, I felt there was definitely a story to tell. As time went by I'd read stuff like John King's The Football Factory and Bill Buford's Among The Thugs. When Milo started knocking out the newer stuff, I read Scally by Andy Nicholls and Tony O’Neill's books, and even they hadn't gone into extensive detail on the subject. Nicholls seemed bored by it and O’Neill was in prison during that time. I really had no idea that it was taking on such 
International Journal of Child, Youth and Family Studies (2012) 1: 65-82

momentum in the U.K., as I live in the States. I discovered Dave Hewitson's The Liverpool Boys Are In Town and finally I'd found someone who knew the history and cared enough to write a book about it. It was Dave that put me onto the 1980s casuals web forum. The very first time I went on the forum, I just sat and tapped out a mad load of pyschobabble about scaly, knobbly, leather, suede and lambswool creatures with multi-coloured trainers and razor sharp claws that attacked each other outside train stations and football grounds.

Hough reported to our interviewer that he used this "pychobabble" to develop these patchwork memories of casual culture into his first book, entitled Perry Boys:

Much of those first few posts on 1980s casuals were pasted verbatim into Perry Boys. I was doing a toxicology degree at the time, and I would use a computer lab at university to log and bang out these epic tales of bacteria and slime and how this gleaming new look has suddenly hatched from the sediment at the bottom of the Irwell and the Mersey. The lads on the forum lapped it up and Dave encouraged me to keep going. Milo were interested from quite an early stage and I just kept extending it and sending Pete Walsh updates. Finally on my birthday, in October 2006, I was now onto a Masters in immunology, and my wife phoned me at the lab. She read out an e-mail from Pete saying they'd decided to go with it. I hit the ceiling and spent the next two months on a biochemical high. I also dropped out of college to become a writer, for better or worse. Gave up a potential career as a drug analyst to be a hooligan authority, but I prefer to think of myself as a social historian. I wanted to tell Manchester's story as opposed to the well-known Merseyside version. Ultimately I felt a responsibility to tell the tale of how, incrementally, a nightclub oriented trend trickled onto the football terraces and changed hooliganism forever. I'll always be grateful that my involvement in football hooliganism and Manchester's dark side enabled me to become a published writer. I have always been a writer, but I never dreamed it would happen because of something like this. I've always considered the Perries as something important, and it needed detailing. I unravel it a lot more in the sequel, Perry Boys Abroad, and there is still so much more to tell.

Hough, as we have seen, regards himself as a social historian of casual youth culture and its intimate connection to soccer hooliganism. Many of the other interviewees in the project felt the same about their "hit and tell" memoirs. It is possible, through the various memoirs and memories collected in this research, to situate football casuals in a youth subcultural timeline from the scuttlers in Manchester and Salford (Davies, 2008) of the late 19th century through teds, rockers, mods, and skinheads of the 1950s and 1960s and suedeheads, rastas, rude boys, Bowie boys and girls, and punks of the 1970s until they join up with B-boys, acid teds, and ravers in the "acid house" years of the late 1980s and early 1990s (Osgerby, 1998, 2004; Redhead, 1990, 1991b). In the present, dominated by cyclical Pop time (Redhead, 1990) and "retromania” where pop culture is addicted to its own past (Reynolds, 2011), these subcultural styles are constantly recycled in various media forms, apparently eternally.

Casual youth culture began as a "post-mod” (Hough, 2009; Hewitt \& Baxter, 2004; Hewitt, 2000; Elms, 2005), post-skinhead subculture in the 1977-1978 football season in 
Britain, initially in the north west of England, arguably first on Merseyside. By the time of widespread debate about "soccer style wars" (McLaughlin \& Redhead, 1985) on the eve of the 1985-1986 soccer season in Britain, several years of growth of specifically football casual culture had meant that a majority of professional league teams' fans in Britain could boast their own casual firm, or very often, multiple casual firms - essentially hooligan gangs based around the locality of fandom around a professional football club. Ian Hough told our interviewer that he respected what had already been written by Phil Thornton (2003) and was inspired to write up his memories, and the casuals' obsessive-compulsive relationship with fashion, music, and soccer:

Phil Thornton's a great writer and [his book] Casuals covered certain aspects of a certain time. Featuring virually every region in Britain through the 1980s obviously led to the book's popularity, as everyone wanted to read their bit. I really enjoyed the first three chapters of Casuals, dealing with the 1977 to 1980s period. By 1983 I was into the scruff look - invented by some of the original Perries in Prestwich at least a year earlier, if not before that - and had gone off on a space trek under the influence of cannabis, acid and speed. We were listening to Paisley Underground music from the U.S. like The Rain Parade, Plasticland and Dream Syndicate. I wasn't much interested in reading about someone discovering the culture in 1984, or what they were wearing in 1986, etc. By 1986 I was banging about Israel and Egypt in a pair of shorts and sandals with the British urchins who'd flew off to the kibbutzim and ended up on construction in the cities. Getting dressed up for the football was a distant memory, obscured by wild drug trips. There was a psychedelic mountain range between the mid and early 1980s, and it had been fun and frightening to surmount. I can be a terrible snob about these things because I am fascinated by beginning and becoming - and this thing began and became in my backyard. Casuals mentions nightclubs where "posses" engaged in dancing contests. I remember there were a good few lads into the casual scene, right into the late 1980s, and they frequented all the clubs, but I don't remember any of them taking it that seriously.

For Hough and many other interviewees in our project the minutiae of the history bizarre to the outsider - were what mattered to the insider.

There were some claims made in Casuals that seemed like total nonsense though. Pete Hooton says he and his scouse mates met some Millwall fans in Newquay in 1977 and they were all wearing the same clothes - Lois jeans matched with Adidas Stan Smith trainers. I mean, what are the chances of that? It would be like finding a kangaroo on one of Jupiter's moons. Stan Smiths came in at the end of 1979 in both Manchester and Liverpool as testified by Robert Wade Smith who worked for Adidas at the time and described how a "phenomenal 2,000 pairs" of the white leather shoe were sold in the run-up to Christmas 1979. That said, Hooton's account of Hillsborough is very moving, especially how he describes it sinking in that all those people they'd seen "unconscious" on advertising hoardings were actually dead. Phil Saxe was the best contributor to Casuals. He was at the head of several fashion waves and he even mentions the first time he ever saw mods in Manchester, in 1964. The mods he describes were wearing knitted long sleeved polo shirts, which were to prove the longest lived aspect of the 
International Journal of Child, Youth and Family Studies (2012) 1: 65-82

whole thing. Several specific items of clothing united Liverpool and Manchester in a single distinctive fashion at the turn of the 1980s. Chief among them were the Adidas cagoule and the Peter Werth long sleeved knitted polo (often in burgundy).

Manchester's Perries had been wearing Peter Werth with the thin hoops for years. It just seemed to complement the wedge hairstyle and the rest of the costume.

Phil Thornton, also one of our contributors to the research project, objected to some of Hough's projections about casual subcultural history, especially the erasure of the crucial black and white youth cultural links in the history of the casuals. As he told the research team, he was:

Not sure where he got the dancing competition thing from as I don't think I mention such a thing although I definitely remember one of our lads entering and winning a dancing competition at a local club. I interviewed him for the hip hop bit in Casuals as he started as a scally then really got into hip hop around 1984 and went on to launch the U.K. chapter of the rocksteady crew with another Runcorn lad who was also a scally then became a b boy. A similar split happened in Manchester circa 1984. The mainly black gangs who hung round the Arndale escalators dressed the same as white kids until the likes of jd-sports opened and the b-boy style took over, which was a retrogressive step really. The white kids were then dressing down in flared cords, golfing jackets, marks's crew necks, etc which I cover in the book, and which I personally participated in and regard as the pinnacle of the whole scally/casual/Perry subculture. As for Peter Hooton's claim re: Stan Smiths/Millwall, I can only print what he told me - I think South London have indeed always been ahead of the game in the capital and there's a photo of a typical soulboy with a punkette on the King's Road in Chris Sullivan's punk book and he's wearing a rockabilly-type shirt, straight jeans and boating shoes. With a different haircut he could well have been a proto scally - also northern soul saw wedges round the same time. Anyway, Hough seems to have personal scores to settle for some reason and seems to have disappeared after 1985 so probably missed the subtle mutations after he decided "it was over". There's a book to be written about the whole retro scally scene in Merseyside from 1983 to 1987, for example, and the manc scene from Perrys to the Happy Mondays’ Lacoste phase could also work as a separate book or essay.

For Ian Hough, the historical origins of casual youth culture are deep and detectable, and required many of the casual subculture memoir books, such as his own two memoirs, to set the record straight. As he emphasised to our interviewer:

We never called it anything, and the only word we had for it was "boys". It was the same in a few places, or else they called themselves "dressers" or "trendies". Quality clothing has always been the same: a template based on trial and error and what works and looks best. Working class people very often are left to work things out on their own, and that's what we did. That nameless fashion was really just working class lads discovering this fact "en masse”. We learnt something that wealthier people already knew and we hammered it to death. You don't forget something like that, whether you continue to wear the clothes or not. Not many writers have accurately depicted the emergence of the "nameless thing”. Some have exaggerated when it happened, but only 
International Journal of Child, Youth and Family Studies (2012) 1: 65-82

with regard to football. Its true origins go way back to the 1950s and 1960s, to beatniks and mods, and on to soul boys, perries and finally the sportswear crowd that caught on across Britain. These scenes all had their pilot fish and core players, people who innovated and moved on once it became popular. It's all the same thread, a torch passed from one generation to the next. Mod clothing, soul music, grafting, snide merchandising, brand marketing - all played their part in shaping it. I suspect it was more dependent on dictation from the fashion cognoscenti than people like to admit, but the Bowie-Perry-Designer overlap from 1979 into mid-1982 was the purest form, the pinnacle. All the conditions were ripe and we literally made it up as we went along, based on gut feeling. The deeper you dig, the more you find. It's hard to know where to draw the line.

For Hough, geographical and historical origins are crucial in making sense of any youth culture, especially casual youth culture with its "ever changing moods" and styles of trainers, haircuts, or tops:

My point was that the north west was what it was really all about, not somewhere else. Everyone else copied the look and the concept, and as such were products of mimicry not innovation. That said, once people started on the case, they often arrived at the same conclusions and had the same tastes. It took a decade or more for the look to become something inside Manchester. From the northern soul boys (the original Perry boys) of 1970 to the Bowie crowd of the mid-1970s, they were a kind of rare mod who you were lucky to see once in a blue moon. The soul-mod look became the Bowie thing around 1975. Between 1975 and 1979 Mancunians were gradually acclimatised to this oddly normal looking form of hipster-hooligan. Side parted wedge hairstyles, baggy small collared shirts, pleated "peg” like trousers or jeans that tapered toward the bottom and sensible shoes weren't what the media was describing as a hooligan outfit, but we knew better. In the papers it was all Glam Rock flare boys in star jumpers. As the soul crowd matured and settled down, these "Bowie Perries" became the elders. When brand marketing (Umbro replica football kits, Adidas T-shirts and sports bags, etc.) became more popular than quality marketing (i.e., well known and respected mod gear), then younger kids around the scene wanted training shoes and tracksuits as much as small collar shirts and boat shoes. The domestic turn towards branding whetted the appetites of those who found Lacoste, Fila, and top of the range Adidas wear on the continent. It wasn't simply scousers going to Europe and coming back with Forest Hills in 1066 or whenever they claim it was.

Hough reveals the hyper-local rivalry between Manchester and Merseyside, only 40 miles apart but since the late 1970s the base of the fiercest (frequently ultra-violent) rivalry in British soccer fandom, that between Manchester United fans and Liverpool fans, and to a lesser extent Manchester City fans and Everton fans. For Hough, casual youth rivalry was intertwined with the inter-city enmity:

It was a process that once set in motion was inevitable. Manchester had been at it for years before the sportswear thing hit. I think Liverpool lacked our Perry pedigree, but they had a Punk-Bowie look all their own, which happened to include narrow trousers 
International Journal of Child, Youth and Family Studies (2012) 1: 65-82

and wedge hairstyles. They went bananas when they discovered the high-end continental clobber and they invented the football casual as a result. Scousers exploded in a couple of years from almost nothing, but Manchester arrived via ten years of subtle mutations. The results were the same in both cases, and the Liverpool look provoked a reaction in the subconscious Manc mind. Those first years, from 1979 to 1982, were the height of it. It was a secret. Only we and the scousers knew anything about it. Most people will say Liverpudlians hit the terraces in proper numbers as a real hooligan movement before Manchester did, and that would be true. The media were hopelessly out of touch with it, and this created a cloaking effect around the north west. There were no nationwide chainstores or TV stars championing the look. It was a working class thing embedded in the football terraces. With all due respect, these lads had a great sense of style but were light years away from penetrating the middle class media fortresses that could have spread the word much earlier. It was all communicated via football matches and curious lads who went shopping in Manchester and Liverpool, eager to learn more about the movement. When you consider that a lot of these boys were behaving violently towards each other, it's a wonder anything was communicated at all. Most of the words between them probably amounted to abuse regarding fashion sense. That means something when you're a teenager, so it caught people's attention. Three years must be the time it takes for a finished product to make its way across the country using such primitive means of dissemination.

Eventually the elitist, secret world of casual youth culture became an "international style” in the 1980s; "everyone” of a certain age, it seemed, suddenly wore casual style ubiquitous trainers, labelled clothing, and moulded, gelled (male) hairstyles. Our interviewee Ian Hough had initially intended his social history of the hidden original "subculture" of casuals to "just focus on the early 1980s but ended up extending it into the rave era of the late 1980s and 1990s, which initially felt like a separate thing”. The casual youth culture overlapped in these years with a range of illegal activities in the "underground economy" of the U.K. (Sugden, 2002, 2007) from soccer violence, using and dealing recreational drugs, through gun running, planning heists, organising ticket touting and horse racing scams, to the routine "bunking in" (entering free) to stadiums and "jibbing” (jumping trains without paying) train rides all over the world (Blaney, 2004; Allt, 2007, pp. 1-9; Hough, 2009). As Ian Hough told our interviewer, one of the books at the edge of the football hooligan memoir genre "nailed" this world of "grafting". The book was by Manchester United fan Colin Blaney, a self-confessed grafter and soccer hooligan:

That was Grafters by Colin Blaney, I loved Grafters, partly because Blaney was from north Manchester and I knew his world, but mainly because he summed up so many aspects of our thing beyond football. I've always thought that the casual look was symptomatic of bigger things than football, and Grafters went into all the slang words, the thieving lifestyles and fashions that changed from the 1970s into the 1980s. I grew up with lads like Blaney and they are wild boys, make no mistake. But their sense of cool was years ahead of its time, and some of the more recent stuff Colin has written is pure brilliance. He basked in the real underground scene in the neighbourhood, as we all did to some extent. The gangsters, the pubs, the accent and slang, and the fashions, all 
International Journal of Child, Youth and Family Studies (2012) 1: 65-82

were crucial pieces in the north Manchester jigsaw. Grafters is like a high speed ride through it all.

\section{Sociology of Youth Culture: A Slight Return}

The research project which I have briefly reported on here contains some insights for the "sociology of youth culture", especially the diverse disciplines of cultural studies on the one hand and criminology on the other, and their specific respective sub-disciplines of postsubcultural studies and cultural criminology; moreover, sub-disciplines which have a growing literature surrounding them on these issues. A considerable rethinking of the concept of youth culture and subculture, as if we are now "after subculture" (Bennett \& Kahn-Harris, 2004) or "beyond subculture” (Huq, 2006), or even beyond "post-subculture”, has taken place over the last decade (Blackman, 2005; Greener \& Hollands, 2006). For instance, originally, the now defunct Centre for Contemporary Cultural Studies (CCCS) produced seminal work at the University of Birmingham in the 1960s and 1970s (Hall \& Jefferson, 2006; Hebdige, 1979). The "Birmingham School" as it became known is infrequently given its due but much of its critique of earlier work on youth culture and youth subculture remains pertinent today. A second edition of its classic collection of essays on youth subcultures in post-war Britain, first published in 1976, the very year before causal youth culture emerged in the United Kingdom, was put out in 2006. Resistance Through Rituals re-emphasised the pioneering nature of the work whilst also coming to terms with more recent approaches such as postmodernism (Hall \& Jefferson, 2006, pp. xix-xxi) and postfeminism (Hall \& Jefferson, 2006, pp. xxiv-xxv). The early work on soccer hooligan subcultures at the Centre for Contemporary Cultural Studies by writers like John Clarke (Hall \& Jefferson, 2006, pp. 80-83) linking skinheads (Daniel \& McGuire, 1972) to soccer hooliganism and the "magical recovery of community" was always exemplary. The origins of the "concept of subculture" in the Chicago School criminology (Jencks, 2005; Blackman, 2005) of the early part of the 20th century risk being erased as new generations of scholars emerge in a new century, and new subcultures such as emo - a label derived from emotional punk (Simon \& Kelley, 2007) - as well as older subcultures like goth (Brill, 2008) and soulboy, especially northern ${ }^{4}$ soul (Wilson, 2007), present themselves for sustained new ethnographic and theoretical analyses in studies of "subcultural style" 5 . As one of our correspondents mischievously put it, "scally emo anyone?”6.

The Manchester Institue for Popular Culture (MIPC) research centre, which ran at Manchester Metropolitan University from 1992 to 2006, at least initially, attempted to constructively revise the CCCS work and, especially, apply new theory to new, emerging subcultures, including football casuals. In fact, the emergence of "clubcultures" and "postsubculture” in this work (Redhead,et al., 1997) as fresh concepts, the subsequent re-imagining of the figure of the "post-subculturalist" by David Muggleton (Redhead et al., 1997), and the development of a sub-discipline of post-subcultural studies rapidly gained pace (Muggleton, 2000; Muggleton \& Weinzierl, 2003; Bennett \& Kahn-Harris, 2004; Greener \& Hollands, 2006) by the end of the 1990s and early 2000s. A symposium held in Vienna, Austria shortly after the turn of the millennium in 2001 entitled "Post-Subcultural Studies: New Formations within Popular Culture and their Political Impact” (Muggleton \& Weinzierl, 2003, p. 3) helped to kickstart this new international sub-discipline which became rather uneasily situated at the 
intersection of criminology, socio-legal studies, sociology, and cultural studies later in the decade.

The discussion of contemporary youth culture literature and the rise and fall of subcultures also illuminates the general state of the sub-discipline of cultural criminology (Katz, 1988; Redhead, 1995; Ferrell \& Sanders, 1995; Ferrell, Hayward, Morrison, \& Presdee, 2004; Presdee, 2000, 2004; Young, Ferrell, \& Hayward, 2008; Hayward, 2004; Zatich \& de Leeuw, 2010). Further, it also touches upon theories of subculture, youth culture, and popular culture overall, an amalgam I once labelled, with heavy irony, "popular cultural studies” (Redhead, 1995, 1997b; Redhead et al., 1997). In a recent series of debates, a binary division between subcultural theorists and post-subcultural theorists has appeared (Greener \& Hollands, 2006; Blackman, 2005). For some theorists such as Blackman (2005) and Bennett (2005), a general postmodern subcultural theory has been identified in these debates which includes postsubcultural theory drawing on such theorists as Jean Baudrillard (Pawlett, 2007; Merrin, 2005; Redhead, 2008a). Some work on subculture, rave, and football hooliganism has been seen, in some ways misleadingly, to be part of this cluster of postmodern subcultural theory (Hollands, 2002; Chatterton \& Hollands, 2003; Greener \& Hollands, 2006; Blackman, 2005; Bennett, 2005) where youth styles are perceived to be "depthless, transitory and internally fragmented" although, as the present essay demonstrates, both the theoretical endeavour and the subcultures themselves have proved to be rather more enduring. Significantly, work on casuals or soccer hooligan subcultures has not featured in this rethinking of subculture in post-subcultural studies, or in the sub-discipline of cultural criminology (Redhead, 1995; Ferrell \& Sanders, 1995; Ferrell et al., 2004; Presdee, 2004), though related studies of contemporary rave culture have figured strongly (Presdee, 2000; Muggleton \& Weinzierl, 2003, pp. 101-117; Bennett \& Kahn-Harris, 2004, pp. 65-78; Gelder, 2007, pp. 64-65; Nayak \& Kehily, 2008, pp. 56-59). Perhaps the reason for this omission is that little sustained sociological and anthropological theorising and rigorous academic ethnography of casual subcultures has been conducted over the last 30 years. This essay, and the research project in general reported on here, partly repairs such gaps.

What the research project reported on here provides, as has been seen in this essay, is a possible cultural criminology supplement for post-subcultural studies. Methodologically it allows academics to add events, conversations, stories, language, and colour to a history of youth culture which was already partly written at the time in the 1970s and 1980s, but which has many roots in soccer fandom even today. Also it stimulates the possibility of repairing the black holes in knowledge of casual youth culture within post-subcultural studies and cultural criminology to provide what I have labelled elsewhere (Redhead, 2008b, 2008c, 2010a, 2010b) as a "post-subcultural criminology" of youth. 
International Journal of Child, Youth and Family Studies (2012) 1: 65-82

\section{References}

Allt, N. (2008). Culture of capital. Liverpool: Liverpool University Press.

Allt, N. (Ed.). (2007). Here we go gathering cups in May: Liverpool in Europe - The fans' story. Edinburgh: Canongate.

Allt, N. (2004) The boys from the Mersey: The story of the Annie Road end crew, football's first clobbered-up mob. Lytham: Milo.

Anderson, T., \& Kavanaugh, P. (2007). A "rave” review: Conceptual interests and analytic shifts in research on rave culture. Sociology Compass, 1(2), 499-519.

Bennett, A. (2005). In defence of neo-tribes: A response to Blackman and Hesmondalgh. Journal of Youth Studies, 8(2), 255-259.

Bennett, A., \& Kahn-Harris, K. (Eds.). (2004). After subculture: Critical studies in contemporary youth culture. Houndmills: Palgrave.

Brabazon, T. (2006). Playing on the periphery: Sport, identity and memory. London: Routledge.

Blackman, S. (2005). Youth subcultural theory: A critical engagement with the concept, its origins and politics, from the Chicago school to postmodernism. Journal of Youth Studies, 8(1), 1-20.

Blackshaw, T., \& Crabbe, T. (2004). New perspectives on sport and “deviance”: Consumption, performativity and social control. London: Routledge.

Blaney, C. (2004). Grafters: The inside story of the wide awake firm. Europe's most prolific sneak thieves. Lytham: Milo.

Brill, D. (2008). Goth culture: Gender, sexuality and style. Oxford: Berg.

Brown, C. (2000). Bovver. London: John Blake.

Brown, C. (2009). Booted and suited. London: John Blake.

Burdsey, D. (2008). British Asians and football: Culture, identity, exclusion. London: Routledge.

Champion, S. (Ed.). (1997). Disco biscuits. London: Sceptre.

Chatterton, P., \& Hollands, R. (2003). Urban nightscapes: Youth cultures, pleasure spaces and corporate power. London: Routledge. 
International Journal of Child, Youth and Family Studies (2012) 1: 65-82

Daniel, S., \& McGuire, P. (Eds.). (1972). The paint house: Words from an east end gang. Harmondsworth: Penguin.

Davies, A. (2008). The gangs of Manchester: The story of the scuttlers, Britain's first youth cult. Wrea Green: Milo.

Elms, R. (2005). The way we wore: A life in threads. London: Picador.

Ferrell, J., Hayward, K., Morrison, W., \& Presdee, M. (Eds.). (2004). Cultural criminology unleashed. London: Glasshouse.

Ferrell, J., \& Sanders, C. (Eds.). (1995). Cultural criminology. Boston: Northeastern University Press.

Gelder, K. (2007) Subcultures: Cultural histories and social practice. London: Routledge.

Greener, T., \& Hollands, R. (2006). Beyond subculture and post-subculture? The case of virtual psytrance. Journal of Youth Studies, 9(4), 393-418.

Hall, S., \& Jefferson, T. (Eds.). (2006). Resistance through rituals: Youth subcultures in postwar Britain (2nd ed.). London: Hutchinson.

Hayward, K. (2004). City limits: Crime, consumer culture and the urban experience. London: Cavendish.

Healy, M. (1996). Gay skins: Class, masculinity and queer appropriation. London: Cassell.

Hebdige, D. (1979). Subculture: The meaning of style. London: Methuen.

Hesmondalgh, D. (2005). Subcultures, scenes or tribes: None of the above. Journal of Youth Studies, 8(1), 21-40.

Hewitson, D. (2008). The Liverpool boys are in town: The birth of terrace culture. Liverpool: Bluecoat Press.

Hewitt, P. (2000). The soul stylists: Forty years of modernism. Edinburgh: Mainstream.

Hewitt, P., \& Baxter, M. (2004). The fashion of football: From best to Beckham, from mod to label slave. Edinburgh: Mainstream.

Hollands, R. (2002). Divisions in the dark: Youth cultures, transitions and segmented consumption spaces in the night-time economy. Journal of Youth Studies, 5(2), 1-20.

Hough, I. (2007). Perry boys: The casual gangs of Manchester and Salford. Wrea Green: Milo.

Hough, I. (2009). Perry boys abroad: The ones who got away. London: Pennant. 
International Journal of Child, Youth and Family Studies (2012) 1: 65-82

Huq, R. (2006). Beyond subculture: Pop, youth and identity in a postcolonial world. London: Routledge.

Jefferson, T., \& Hall, S. (Eds.). (2006). Resistance through rituals: Youth subcultures in post-war Britain. London: Hutchinson.

Jencks, C. (2005). Subculture. London: Sage.

Jones, O. (2011). Chav: The demonisation of the working class. London: Verso.

Katz, J. (1988). Seductions of crime. New York: Basic Books.

Khan, R. (2010). Khan: Reflections of an Asian football casual. London: Pennant.

McLaughlin, E., \& Redhead, S. (1985, August). Soccer's style wars. New Society, 73(1181), 225-228.

Merrin, W. (2005). Baudrillard and the media. Cambridge: Polity.

Muggleton, D. (2000). Inside subculture: The postmodern meaning of style. Oxford: Berg.

Muggleton, D., \& Weinzierl, R. (Eds.). (2003). The post-subcultures reader. Oxford: Berg.

Nayak, A., \& Kehily, M. J. (2008). Gender, youth and culture: Young masculinities and femininities. Houndmills: Palgrave Macmillan.

Osgerby, W. (2004). Youth media. London: Routledge.

Osgerby, W. (1998). Youth in Britain since 1945. Oxford: Blackwell.

Pawlett, W. (2007). Jean Baudrillard. London: Routledge.

Presdee, M. (2000). Cultural criminology and the carnival of crime. London: Routledge.

Presdee, M. (2004). The long and winding road of cultural criminology. Theoretical Criminology (Special issue: Cultural criminology), 8(3), 275-285.

Redhead, S. (1987). Sing when you're winning: The last football book. London: Pluto Press.

Redhead, S. (1990). The end-of-the-century party (with photos by Kevin Cummins). Manchester: Manchester University Press.

Redhead, S. (1991a). Football with attitude. Manchester: Wordsmith. 
International Journal of Child, Youth and Family Studies (2012) 1: 65-82

Redhead, S. (1991b). An era of the end, or the end of an era? Football and youth culture in Britain since the 1950s. In S. Wagg \& J. Williams (Eds.), British football and social change. Leicester: Leicester University Press.

Redhead, S. (Ed.). (1993a). Rave off: Politics and deviance in contemporary youth culture. Aldershot: Avebury.

Redhead, S. (Ed.). (1993b). The passion and the fashion: Football fandom in the new Europe. Aldershot: Avebury.

Redhead, S. (1995). Unpopular cultures: The birth of law and popular culture. Manchester: Manchester University Press.

Redhead, S. (1997a). Post-fandom and the millennial blues: The transformation of soccer culture. London: Routledge.

Redhead, S. (1997b). Subculture to clubcultures: An introduction to popular cultural studies. Oxford: Basil Blackwell.

Redhead, S. (2000). Repetitive beat generation. Edinburgh: Rebel Inc/Canongate.

Redhead, S. (2004). Hit and tell: A review essay on the soccer hooligan memoir. Soccer and Society, 5(3), 392-403.

Redhead, S. (Ed.). (2008a). The Jean Baudrillard reader. Edinburgh: Edinburgh University Press/New York: Columbia University Press.

Redhead, S. (2008b). Firms, crews and soccer thugs: The slight return of football hooligan subcultures. In K. Young \& M. Atkinson (Eds.), Tribal play: Subcultural journeys through sport (Research in the Sociology of Sport, Vol. 4). Bradford: JAI, Emerald.

Redhead, S. (2008c). Emotional hooligan: Post-subcultural research and the histories of Britain's football gangs. Entertainment and Sports Law Journal, 5(2). http://www2.warwick.ac.uk/fac/soc/law/elj/eslj/issues/volume5/number2/redhead

Redhead, S. (2008d). Whatever happened to the likely lads? Ten years after the repetitive beat generation. Rock'sbackpages http://www.rocksbackpages.com/article.html?ArticleID=12731

Redhead, S. (2010a). Little hooliganz: The inside story of glamorous lads, football hooligans and post-subculturalism. Entertainment and Sports Law Journal, 8(2). http://www2.warwick.ac.uk/fac/soc/law/elj/eslj/issues/volume8/number2/redhead

Redhead, S. (2010b). Lock, stock and two smoking hooligans: Hit and tell literature and low sport journalism. Soccer and Society, 11(5), 627-642. 
International Journal of Child, Youth and Family Studies (2012) 1: 65-82

Redhead, S. (2011). We have never been postmodern: Theory at the speed of light. Edinburgh: Edinburgh University Press.

Redhead, S., Wynne, D., \& O’Connor, J. (Eds.). (1997). The clubcultures reader: Readings in popular cultural studies. Oxford: Basil Blackwell.

Reynolds, S. (2011). Retromania: Pop culture's addiction to its own past. London: Faber.

Sampson, K. (1998). Awaydays. London: Jonathan Cape.

Simon, L., \& Kelley, T. (2007). Everybody hurts: An essential guide to emo culture. New York: Harper.

Sugden, J. (2002). Scum airways: Inside football's underground economy. Edinburgh: Mainstream.

Sugden, J. (2007). Inside the grafter's game: An ethnographic examination of football's underground economy. Journal of Sport and Social Issues, 31(3), 242-258.

Thornton. P. (2003). Casuals: Football, fighting and fashion. The story of a terrace cult. Lytham: Milo.

Welsh, I., \& Cavanagh, D. (2007). Babylon heights. London: Vintage.

Wilson, A. (2007). Northern soul. Cullompton: Willan.

Woods, A. (2011). No one likes us, we don't care: True stories from Millwall, Britain's most notorious football hooligans. London: John Blake.

Young, J., Ferrell, J., \& Hayward, K. (Eds.). (2008). Cultural criminology: An invitation. London: Sage.

Zatich, D., \& de Leeuw, T. (2010). Fighting with images: The production and consumption of violence among online football supporters. In K. Hayward \& M. Presdee (Eds.), Framing crime: Cultural criminology and the image. London: Routledge. 
International Journal of Child, Youth and Family Studies (2012) 1: 65-82

\section{Endnotes}

1 The larger research project mapped the entirety of soccer hooligan gangs of Britain from the 1960s to the present day - partly through the development of a research archive of individual soccer hooligan memoirs by various publishers from 1987 to the present day. The research project collected nearly a hundred football hooligan memoirs from this period in book form, ranging from the well written to the barely literate. The latest of these memoirs is on Millwall (Woods, 2011). They are still being published, if only occasionally.

2 In the same year, 2009, there was also a cinematic remake of Alan Clarke's 1980s "realist” TV drama The Firm. The Firm was directed by The Football Factory film director Nick Love and could easily have been dubbed The Football Factory 2 given the continued concentration on certain aspects of London casual style, whereas Awaydays highlights the nuances of casual culture on Merseyside in the late 1970s.

3 Glamorous Hooligan is actually the name of a Bradford dance culture duo formed in the 1990s comprising Enzo Annechinni and Dean Cavanagh (aka DJ Sal). Dean Cavanagh, who contributed "Mile High Meltdown" to Sarah Champion's anthology of "fiction from the chemical generation" (Champion, 1997), became the writing partner of Trainspotting author Irvine Welsh (Redhead, 2000, 2008d) - see for example Welsh and Cavanagh, 2007.

${ }^{4}$ In 2010 a feature film called SoulBoy directed by Shimmy Marcus was released which "fictionally" but faithfully reconstructed the "Northern" or "Northern Soul” scene in Britain in the 1970s.

5 Berg, for instance, recently commissioned a new international book series called Subcultural Style - Body Style, Queer Style, Punk Style, Fetish Style are forthcoming from Berg.

6 Author of Casuals, Phil Thornton, a Manchester United soccer fan living on Merseyside, pointed out to me in correspondence for the research project that such new subcultures as "scally emos" do exist but they are not in the purview of the so-called journalists of style culture (in the U.K., usually London-based) who pervade the British and indeed international media. Thornton, inspired by print fanzines like Sniffin Glue, The End, Herb Garden, and Boys Own (Redhead, 1991b, 1997a), has been prominent for many years in taking the fanzine concept to the Internet through e-zines; see for instance, www.swinemagazine.co.uk. 